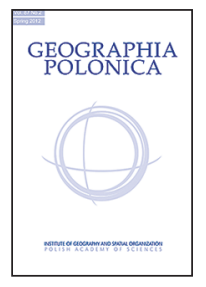

\title{
VARIABILITY OF THE SNOW AVALANCHE DANGER IN THE TATRA MOUNTAINS DURING THE PAST NINE DECADES
}

\author{
Bogdan Gqudek ${ }^{1,2}$ • Mariusz Grabiec ${ }^{1,2}$ • Zofia Rączkowska ${ }^{3}$ \\ Andrzej Maciata ${ }^{4}$ \\ ${ }^{1}$ Faculty of Earth Sciences \\ University of Silesia in Katowice \\ Będzińska 60, 41-200 Sosnowiec: Poland \\ e-mails: bogdan.gadek@us.edu.pl • mariusz.grabiec@us.edu.pl \\ ${ }^{2}$ Centre for Polar Studies \\ University of Silesia in Katowice \\ Będzińska 60, 41-200 Sosnowiec: Poland \\ ${ }^{3}$ Institute of Geography and Spatial Organization \\ Polish Academy of Sciences \\ Św. Jana 22, 31-018 Kraków \\ e-mail: raczk@zg.pan.krakow.pl \\ ${ }^{4}$ Tatra Volunteer Rescue Service \\ Piłsudskiego 63A, Zakopane: Poland \\ e-mail: am@topr.pl
}

\begin{abstract}
In order to recognise the variability of the snow avalanche danger in the Tatra Mountains, the danger levels on consecutive days with snow cover over the last nine decades were calculated. To accomplish this task, the longest series of meteorological data were used from the Tatras along with an empirical method for determining the regional avalanche danger on the basis of elementary meteorological data. The results point to the fact that over the last 25 years the number of days with a level 2 avalanche danger significantly decreased, whereas the number of days with level 1 increased. This should result in a decreasing trend in the incidence of small and medium-sized natural avalanches. In the structure of snow cover, the percentage of melt forms might increase. However, this should not correlate with a significant increase in wet-snow avalanches, because the number of days with wet snow also reduces. The contemporary changes in the snow conditions and avalanche danger in the subalpine belt of the Tatras have been primarily associated with an increase in the air temperature (shorter winters and less snow).
\end{abstract}

\section{Key words}

snow avalanche $\cdot$ avalanche danger - climate danger - the Tatra Mountains 


\section{Introduction}

The contemporary warming of the Earth's climate results in, among others, changes in the duration and thickness of snow cover (Vaughan et al. 2013). In mountain areas, it may also correspond with changes in the activity of snow avalanches (Eckert et al. 2013).

Snow avalanche occurrences depend on local conditions for the development of snow cover, its physical properties, and external impulses (e.g. Schweizer et al. 2003). The likelihood of the occurrence, possible size and distributions of avalanches in a specific region is described by the level of avalanche danger (WSL 2014). It is assessed by national meteorological and avalanche warning services.

In the Polish Tatras, avalanche warnings have been applied since the 1930s. Initially, they had a purely descriptive character (Bartnicki \& Leszczycki 1934). The numerical scale of the danger was introduced in 1978. It was a three-level scale (1-no danger, 2-danger, 3-alarm). In the 1980s, a four-level risk scale was adopted (1-low risk, 2-moderate, 3-high, 4-alarm), and detailed instructions for forecasting snow avalanches were developed (Kłapowa 1989). It was based primarily on the observations of the weather and snow conditions measured at two year-round meteorological stations: on Hala Gqusienicowa (1520 m a.s.l.) and at Kasprowy Wierch (1991 m a.s.l.). In the mid 1990s, the 5-level European avalanche danger scale was adopted (Bartkowski 2014). Nonetheless, the determination of the long-term trend in the avalanche danger on the basis of all previous records would not be possible because of their non-uniform character. This is especially due to multiple changes in the scale and guidelines, and the differences in the expertise and experience of those involved in the danger assessment.

The aim of this study is to identify the variability of the avalanche danger in the Tatra Mountains during the last nine decades as well as its trend and relationship with climate change. Of key importance were calculations of the level of avalanche danger in consecutive days for every winter season. To accomplish this task the longest series of meteorological data from the Tatras were used along with an empirical method for determining the regional avalanche danger on the basis of elementary meteorological data.

\section{Regional settings}

The Tatra Mountains are the highest range in the Carpathians arc. They occupy approximately $790 \mathrm{~km}^{2}$ (Balon et al. 2015), whereas approximately $4 / 5$ belongs to Slovakia, and the remainder to Poland (Fig. 1). The highest peak within the borders of Poland (Rysy) rises up to approximately $1000 \mathrm{~m}$ above the timberline reaching $2499 \mathrm{~m}$ a.s.l. The Tatras are characterised by an alpine relief (e.g. Raczkowski et al. 2015), which was formed during the Pleistocene glaciations (e.g. Klimaszewski 1988). The climatic snow line currently runs at an altitude of about 2600 m a.s.l. (Zasadni \& Kłapyta 2009). On the other hand, the orographic snow line at the northern side of the Tatras is delimited by firn-ice patches nourished by snow avalanches, down to $1530 \mathrm{~m}$ a.s.l. (e.g. Wiśliński 1985; Jania 1997). The present-day climate is transitional between maritime and continental influences. The mean annual air temperature (MAAT) at the northern Tatras' foothills is $6^{\circ} \mathrm{C}$. At the highest summits, MAAT is $-2{ }^{\circ} \mathrm{C}$ (Żmudzka et al. 2015). The mean total precipitation ranges from approximately $1100 \mathrm{~mm}$ in the north foothills to more than $2000 \mathrm{~mm}$ in higher parts (Ustrnul et al. 2015), and the number of days with seasonal snow cover ranges from about 100 to over 220, respectively (Ustrnul et al. 2015; Gadek \& Szypuła 2015).

In the second half of the 20th century and the first decade of the 21st century, a decrease in the number of days with snow cover and of the maximum thickness of snow cover was registered in the Tatras (Falarz 

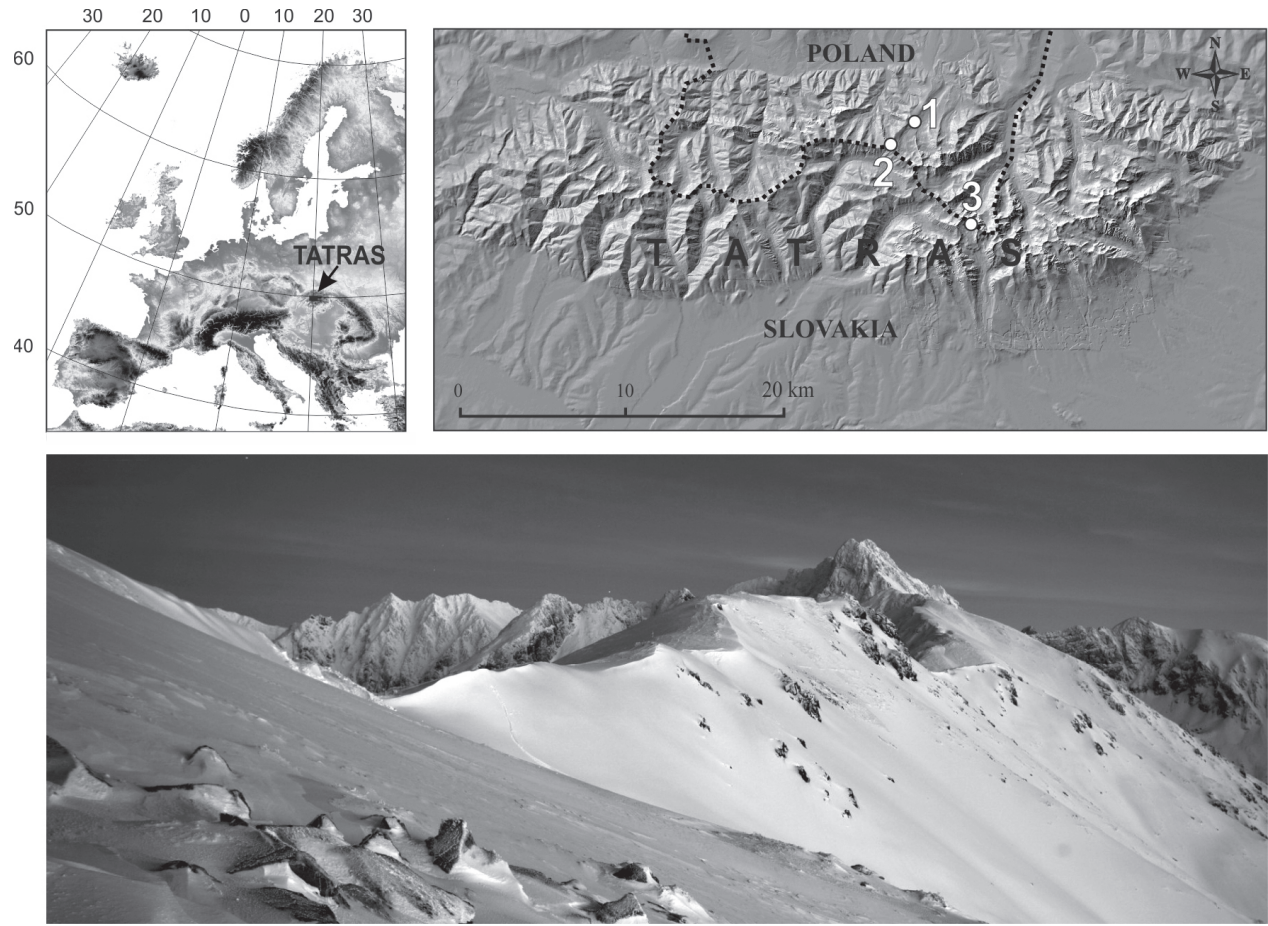

Figure 1. Location of the study area: 1 - meteorological station on Hala Gqisienicowa; 2 - synoptic station at Kasprowy Wierch; 3 - Mięguszowiecki glacieret (perennial avalanche cone) (Photo of the Tatra Mountains by W. Kaszkin)

2002; Gądek \& Leszkiewicz 2012). These changes were consistent with an increase in the air temperature in winter and summer seasons, and with a decrease in snowfall (Żmudzka 2011; Gqadek 2014).

\section{Data and methods}

\section{Meteorological data}

Daily values of the snow depth, air temperature, precipitation and wind speed at the Nival Research Station of the Institute of Meteorology and Water Management on Hala Gasienicowa (Fig. 1) were applied. They included the hydrological years (November-October) from 1927 to 2015 (with a data gap from the period of 1940-1946). On this basis, the weather and snow conditions and the level of avalanche danger were determined for each day with snow cover.

\section{Assessment of avalanche danger}

To assess the level of avalanche danger, an empirical method was employed, which had been used as an auxiliary method in the Tatras in the 1990s. It has been adapted to the five-level European danger scale (EAWS 2016 - www.avalanches.org). The avalanche danger level (adl) in successive days with snow cover was linked with the total of the weights ( $w$ ) of all the input variables indicated in Table 1 as follows: 1adl: $w \leq 20$, 2adl: $20<w \leq 40,3$ adl: $40<w \leq 60$, 4adl: $60<w \leq 80$ and 5 adl: $w>80$. What constituted the input variables were (i) meteorological data and (ii) the type of surface underlying the layer of new snow determined on the basis of the data (Tab. 1). In the latter case it was assumed that a decrease in the thickness of snow cover is the result of settlement basically when the air temperature is negative 
and the wind is not strong. The increase in the wind speed above the threshold value causes snow drifts (e.g. Liston \& Sturm 1998) and a significant increase of the snow density; consequently, a wind crust or wind slab is created. During the periods when the average daily temperature is $\geq 0^{\circ} \mathrm{C}$, snow melts and contains water in the liquid phase. Another decrease in the air temperature below $0^{\circ} \mathrm{C}$ causes the formation of rounded polycrystals. At the same time, the supercooled raindrops coalescing on the surface of snow cover forms a rain crust - i.e. a thin surface glaze (Fierz et al. 2009).

Table 1. Input variables used in the calculations of avalanche danger

\begin{tabular}{|c|c|}
\hline Description & Weight $[\mathrm{w}]$ \\
\hline \multicolumn{2}{|c|}{ Snow depth } \\
\hline$\leq 20 \mathrm{~cm}$ & 0 \\
\hline $20-50 \mathrm{~cm}$ & 2 \\
\hline$\geq 50 \mathrm{~cm}$ & 4 \\
\hline \multicolumn{2}{|c|}{ Surface of the old snow cover } \\
\hline Rounded polycrystals & 2 \\
\hline Wet snow & 3 \\
\hline Settled snow & 4 \\
\hline $\begin{array}{l}\text { Ice formations, wind } \\
\text { crust/wind slab }\end{array}$ & 5 \\
\hline \multicolumn{2}{|c|}{ Depth of new snow } \\
\hline $1 \mathrm{~cm}$ & 1 \\
\hline $5 \mathrm{~cm}$ & 5 \\
\hline $8 \mathrm{~cm}$ & 8 \\
\hline etc. & etc. \\
\hline \multicolumn{2}{|c|}{ Wind speed } \\
\hline Calm & 0 \\
\hline $1-10 \mathrm{~m} / \mathrm{s}$ & 5 \\
\hline$\geq 10 \mathrm{~m} / \mathrm{s}$ & 8 \\
\hline \multicolumn{2}{|c|}{ Air temperature } \\
\hline$\leq-10^{\circ} \mathrm{C}$ & 5 \\
\hline$-10^{\circ} \mathrm{C} \div-5^{\circ} \mathrm{C}$ & 3 \\
\hline$-5^{\circ} \mathrm{C} \div 0^{\circ} \mathrm{C}$ & 4 \\
\hline$\geq 0^{\circ} \mathrm{C}$ & 5 \\
\hline \multicolumn{2}{|c|}{ Exposure to wind } \\
\hline Windward & 0 \\
\hline Leeward & 10 \\
\hline
\end{tabular}

For the purpose of the validation of the results of the calculations of avalanche dan- ger with the aforementioned method, the archival avalanche warnings announced by the Tatra Volunteer Rescue Service (TOPR) were used, and thus a proportional correspondence between the observed and calculated danger was determined. The warnings came from the winter seasons of 2012/2013, $2013 / 2014$ and 2014/2015. The level of avalanche danger indicated for them was evaluated on the basis of a comprehensive analysis of the results of manual observations and automated measurements at snow and weather stations, as well as forecast weather conditions in the Tatras.

The number of days with each individual level of danger, the total of the levels of danger and its average value in subsequent years were also estimated. Moreover, minimum and maximum values, arithmetic average with standard errors and standard deviations of all data were calculated, as well as 11-year moving averages. Trends of changes in annual values, characterised by a normal distribution, were determined by the method of least squares linear regression, and their statistical significance was checked with a t-test (significance level $\alpha \leq 0.05)$. In order to demonstrate the climatic background of the changes in avalanche danger, the following values were calculated: the average air temperature in winter half-years, the number of days with snow cover, the maximum snow depth, and the number of snowmelt days in consecutive years, together with the trends in their longterm variability.

\section{Results and interpretations}

\section{Avalanche danger: calculations vs. observations}

The results of the validation of the method for assessing the level of avalanche danger based on weather and snow elementary data collected on Hala Gasienicowa are shown in Fig. 2. During the three subsequent winter seasons, the results of the calculations were mostly in line with the TOPR avalanche warnings ( $61 \%$ of cases). On the remainder of the days, the calculated danger was by 1 point 

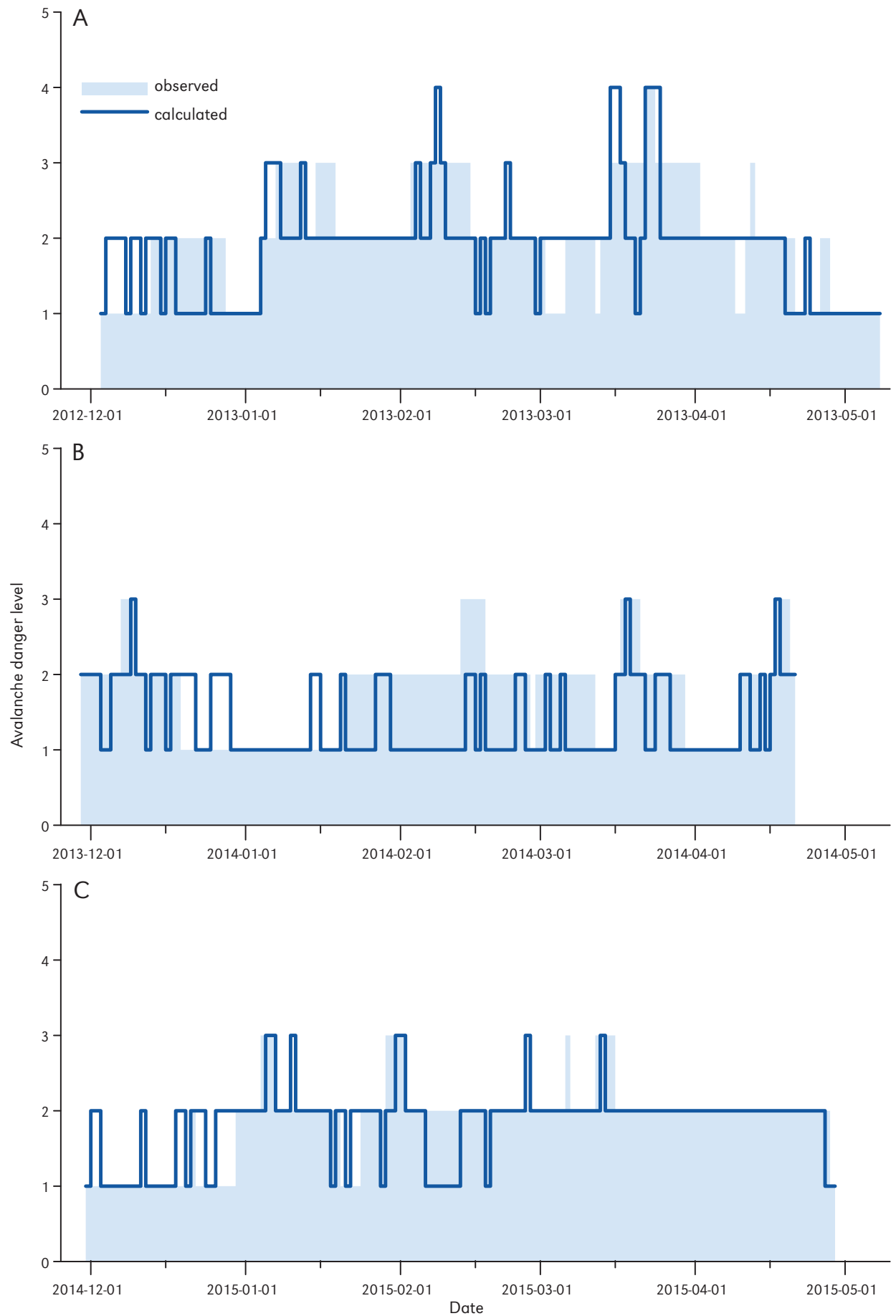

Figure 2. Observed and calculated level of avalanche danger in the Polish Tatras in winter seasons 2012/2013 (A), 2013/2014 (B) and 2014/2015 (C) 
lower $(29 \%)$ or 1 point higher (10\%) than the danger observed. The greatest congruence between the calculated and observed danger $(73 \%)$ was achieved in the winter season of 2014/2015. The days on which the announced avalanche danger was actually by 1 point higher than the calculated danger, accounted for $17 \%$ of all the cases. The $10 \%$ remainder were the days on which the observed danger was by 1 point lower than the calculated danger. The lowest congruence between the calculation results and the observations (52\%) was noted in the winter season of 2013/2014. The percentage of the days on which the level of avalanche danger announced in the TOPR warnings was about 1 point greater or 1 point lower than the danger calculated for the purposes of this study was, then, respectively, $42 \%$ and $6 \%$. The meteorological data used indicate that the winter of 2013/2014 was very warm and with little snowfall.

In the three winter seasons analysed, TOPR service most often announced a level 2 avalanche danger, more rarely level 1 and 3 , and very occasionally level 4 (Fig. 3a). Referring to the results of the calculations, the danger in the Polish Tatras was also assessed as usually moderate. The numbers of days with a level 1 and 2 avalanche danger, calculated on the basis of meteorological data from Hala Gasienicowa, were a few percent higher than the corresponding numbers of the days reported in the archive avalanche warnings. Therefore, the percentage of days with a level 3 danger was lower than the figure resulting from the observations. In contrast, days with a level 4 avalanche danger were more numerous (Fig. 3b). The first case may be the result of the relatively low location of the meteorological station (1520 m a.s.l.), at which the input data was collected (Tatra Volunteer Rescue Service forecast is based on observations also in the highest parts of the Tatras). The remainder of the miscalculations of the danger is connected with the dominant influence of the thickness of the new snow layer on the results of the calculations (Tab. 1). Other variables, including the total thickness of the snow cover and its structure, are of lesser significance during snowfall.

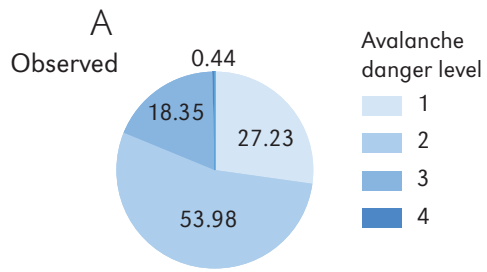

B

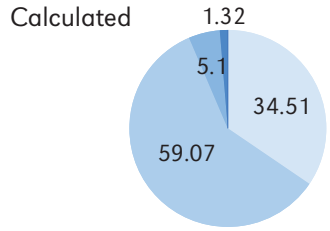

Figure 3. Percentage of observed (A) and calculated (B) avalanche danger in the Polish Tatras in 2012-2015

Therefore, taking into consideration both the scope of congruence and all the discrepancies between the calculated and observed danger, as well as their character, it can be concluded that the obtained results are satisfactory. However, they should be primarily related to the subalpine belt, which extends from the timberline to the altitude of approximately 1800 m a.s.l. (Kotarba 1976).

\section{Long-term variability and changes of the avalanche danger}

The results of the calculations of the avalanche danger in the years 1927-2015 are presented in Figure 4.

The annual totals of the avalanche danger levels in successive seasons with snow cover (Fig. 4a) ranged from 208 (in 2014) to 480 (in 1932). The arithmetic average ( \pm standard error) and standard deviation were, respectively: $360.96( \pm 5.7)$ and 51.3 . The results of the analysis of the 11-year moving averages point to the fact that in the second half of the 20th century the total of the danger levels decreased by the mid-1970s. After that, its values increased until the mid-1980s. In the 

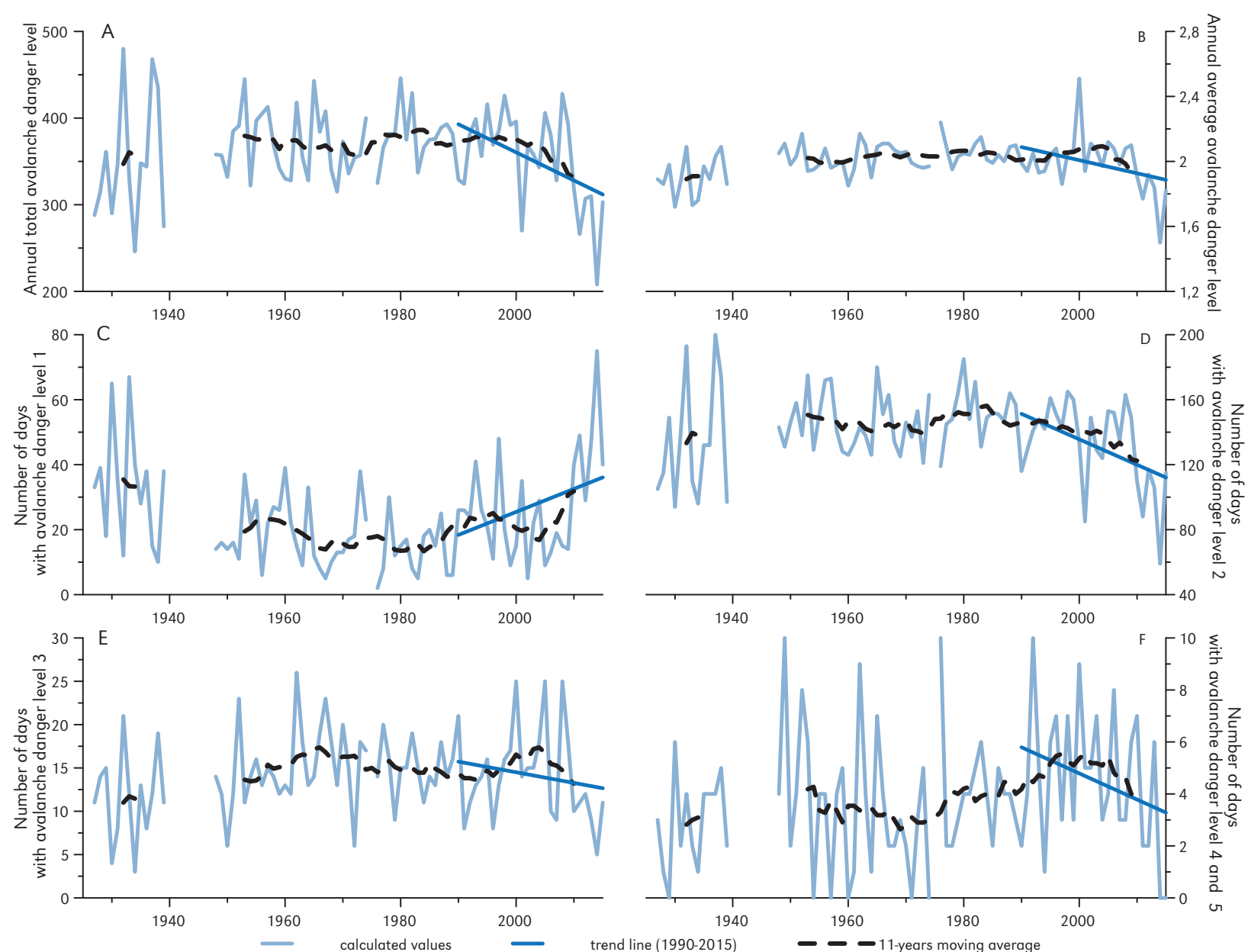

Figure 4. Long-term variability and trends of the calculated avalanche danger in the subalpine belt of the Polish Tatras 
next two decades they were lower, however, no significant variability among them was observed. Since 2003 they have been clearly decreasing again.

The average level of the danger (Fig. 4b) reached the values from 1.5 (in 2014) to 2.51 (in 2000). The arithmetic average was close to $2( \pm 0.015)$ and the standard deviation was 0.134. In the second half of the 20th century, the values of the moving average decreased until 1959, then during the following eight years they slowly increased, and later-until the mid-1980s-they were close to 2. After that, they slowly declined until 1993. Another increase in the values reached its maximum in 2004. Since then, they have been rapidly decreasing.

The number of days with level 1 of the avalanche danger (Fig. 4c) ranged from 7 (in 1967, 1983 and 2002) to 75 (in 2014). The arithmetic average and standard deviation were, respectively: $23.32( \pm 1.65)$ and 14.85 . The moving average increased in the 1950s, 1980s, early 1990s and after 2004. In contrast, it clearly decreased in the early 1960s, late 1990s and at the beginning of the 21st century. In the late 1960s, 1970s and early 1980s, the values were low and did not differ substantially.

The number of days with a level 2 avalanche danger (Fig. 4d) ranged from 59 (in 2014) to 200 (in 1937). The average value was $139.69( \pm 2.81)$ and the standard deviation - 25.28. In the second half of the 20th century, the moving average gradually decreased until 1973, whereas for the next 10 years it increased. In contrast, since 1983 its values have been gradually decreasing. The pace of these changes has been particularly fast since 2004.

The number of days with a level 3 avalanche danger (Fig. 4e) ranged from 5 (in 2014) to 26 (in 1962). The arithmetic average and standard deviation were, respectively: $14.04( \pm 0.56)$ and 5.01. Since the peak in 1966, the moving average gradually decreased until 1994. The next maximum was reached in 2004. During the last several years it has been declining rapidly.
Levels 4 and 5 avalanche danger (avalanche alarm) did not occur every year of the analysed multi-year record (Fig. 4f), however the greatest number of days with such a high risk reached the value of 10 (in 1949). The average number of the days with the avalanche alarm was $3.8( \pm 0.28)$, and the standard deviation was equal to 2.54 . The moving average reached the maximum in 1954, before it decreased until 1969. Then it gradually increased until 1996. In the following decade, its values did not show a high variability. Since 2005 they have been clearly declining.

Based on the obtained data, it has been concluded that the avalanche danger in the past nine decades has not developed any statistically significant trend with regard to the subalpine belt of the Polish Tatras. However, in the last quarter of the century, the number of days with level 1 has very clearly increased, whereas the number of days with level 2 of the danger has decreased ( $p \leq 0.05)$. The variability of the number of the days on which the level of the danger was 3,4 or 5 was also characterised by a linear downward trend; however, it was not statistically significant $(p>0.1)$.

The aforesaid changes were accompanied by an increase in the air temperature and a decrease in the duration and depth of snow. Along with the decrease of the number of days with snow cover, the number of days with snowmelt has been decreasing as well. However, their percentage in the winter season does not point to any trend (Fig. 5).

\section{Discussion}

The empirical method for determining the level of avalanche danger employed for the purpose of this study is not currently in use. It is a simplified version of the guidelines on how to forecast avalanches in the Polish Tatras, developed by Kłapowa (1989). This in turn referred to the American guidelines from the 1960s, which were developed on the basis of several years' observations of the weather and snow conditions and avalanche events in the area of the Berthoud Pass in the 

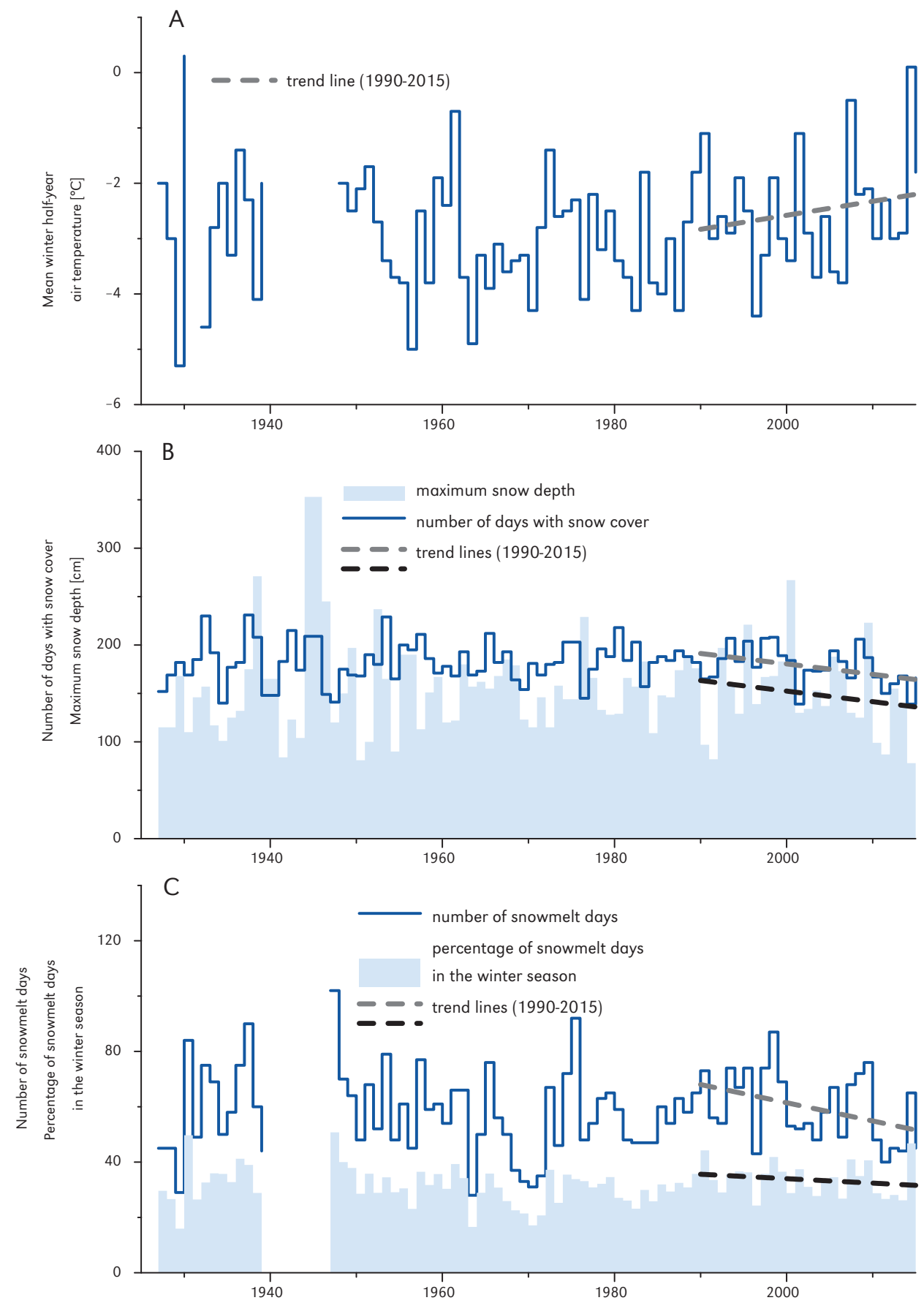

Figure 5. Long-term variability and trends of winter air temperature and snow cover at Hala Gqsienicowa 
Rocky Mountains (after Kłapowa 1968). Currently, avalanche warning services are recommended to make use of: a) manual observations (physical properties and stability of the snow cover on slopes, snowdrift accumulations, danger signs and avalanche events), b) automated snow and weather stations, c) other information such as remote sensing, d) snowpack models and e) weather models (Winkler 2015). However, the data collected in this way in the Tatras are not uniform and cover only the last few years. In contrast, the applied method enables determining the avalanche danger based on the results of elementary meteorological measurements, and thus, it allowed using the longest collected data series in the Tatras above the timberline (on Hala Gasienicowa). The results of the validation of this very simple method ( 60\% hits) are similar to the accuracy of more advanced statistical forecasting of regional avalanche danger (Brabec \& Meister 2001; Schirmer et al. 2009). At the same time, the accuracy of the calculations carried out might be higher if the weather and snow observations from the higher parts of the Tatras-Dolina Pięciu Stawów Polskich valley (precipitation station) and Kasprowy Wierch Mount (synoptic station)-were taken into account. However, the series of the meteorological data from these sites encompass only several decades (Falarz 2001). In addition, at Kasprowy Wierch, there are considerable problems with carrying out snowfall measurements due to the location of the station at the top, and therefore, the snow blowing conditions that are present.

The obtained results indicate that the avalanche danger in the subalpine belt of the Tatra Mountains within the last nine decades has not developed a clear trend. However, what has been observed is a significant decrease in the number of days with moderate avalanche hazard, when a natural triggering of large avalanches is not expected. On the other hand, the timberline in the Tatras rises mainly in the runout zone of very large avalanches (Kaczka et. al. 2015), whereas their return period may exceed 100 years (e.g. McClung \& Schaerer 2006). It may thus be concluded that perhaps the analysed period of nine decades is too short to capture the trend of the high danger.

The declining number of days with a level 2 avalanche danger can primarily be correlated with a lower number of small and medium-sized avalanches and a reduction in the number of avalanche accidents, which in the Tatras take place most frequently on the days of the occurrence of moderate avalanche danger (Marasek 2008). However, there is a lack of systematically monitoring natural avalanches, and moreover, it is difficult to draw conclusions about the climatic conditioning of the variability of the avalanche occurrences because of the dynamic development of winter tourism, educational programmes and information systems warning about the danger. Nevertheless, the obtained results are reflected in the recession of the Tatra glacierets (e.g. Wiśliński 1985; Adamowski \& Wiśliński 2010), most of which are multiannual avalanche cones (Gadek 2008). The variability of these small firn and ice patches (Fig. 6) depends on their winter and summer mass balance. In recent decades, however, the most significant fact was the avalanche nourishing (Gqadek 2008; Gqqdek 2014).

The denoted decrease in the number of days with snowmelt suggests a reduction in wet-snow avalanches. Similar results were obtained by Martin et al. (2001) in the French Alps, who indicated that the avalanche hazard might decrease slightly in winter and more in spring. These authors assumed an increase in both the air temperature and precipitation, determining, on an experimental basis, the critical temperature at which precipitation turns from snow to rain. In the Tatras, climate warming is accompanied by a decrease in snowfall (Żmudzka 2011; Gądek \& Leszkiewicz 2012). Similar trends are also observed for other mountains of Europe, distant from the Tatras (e.g. López-Moreno 2005; LópezMoreno \& Vicente-Serrano 2007) and other continents (e.g. Chun-Yu et al. 2013). Therefore, the obtained results reflect the contemporary changes in the climate system of the Earth (Gqdek 2014). Given the expected 

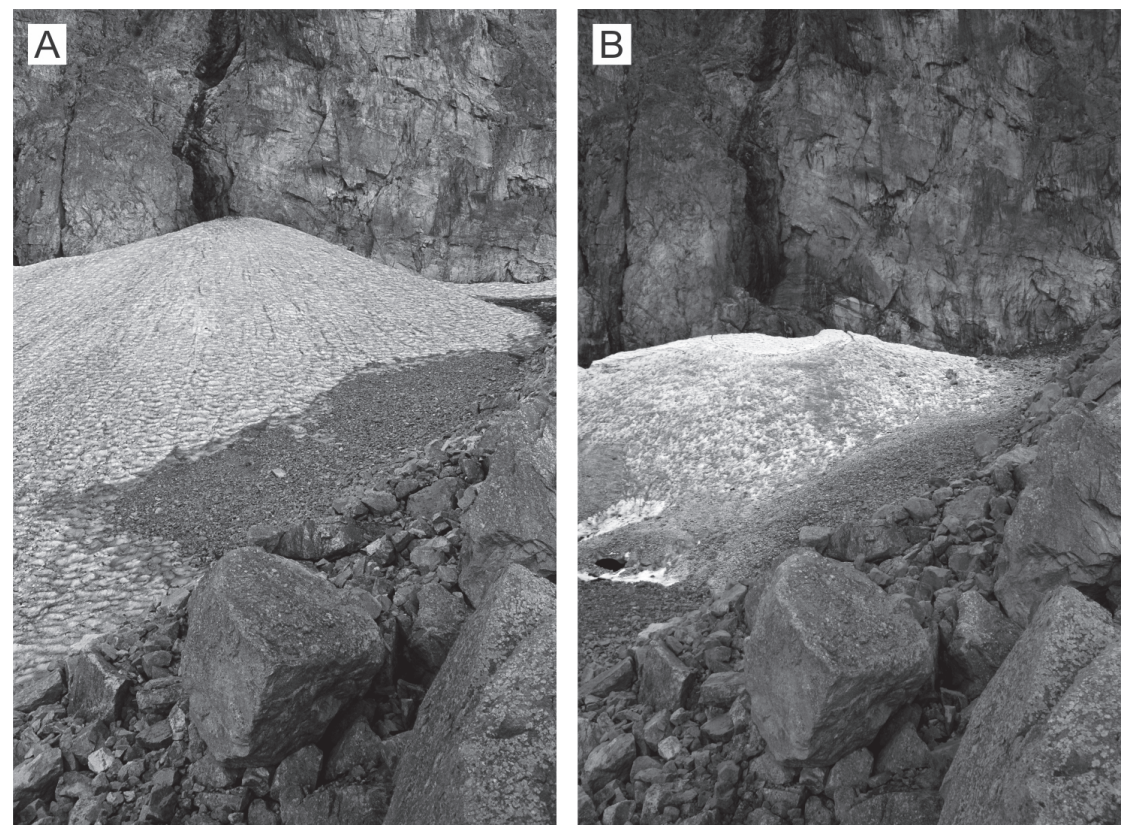

Figure 6. Mięguszowiecki glacieret - the perennial snow avalanche cone in September 1998 (A) and September 2015 (B) (Photos by B. Gqdek)

further increase in the air temperature and decrease in snowfall (IPCC 2013), it may also be assumed that a further reduction of the avalanche danger and an increase in the ratio of the number of days with wet snow to the number of days of dry snow will occur.

\section{Summary and conclusions}

1. The variability of the seasonal snow cover and snow avalanche danger in the Polish Tatras analysed for the period from 1927 to 2015 showed no statistically significant trend.

2. During the past 25 years, the variability of the number of days with seasonal snow cover and the variation of its thickness has been characterised by a clear downward trend. Also, the number of days with a level 2 avalanche danger has been decreasing, while the number of days with a level 1 danger has been growing. This should result in a decreasing occurrence of small and medium-sized natural avalanches.
3. In the structure of snow cover, the proportionate percentage of melt forms might increase. However, this should not correlate with a significant increase in wet-snow avalanches, because, due to the decrease in the thickness and duration of snow cover, the number of days with wet snow also reduces.

4. The contemporary changes in the snow conditions and avalanche danger in the subalpine belt of the Polish Tatras are primarily associated with an increase in the air temperature (shorter winters and less snow).

\section{Acknowledgements}

We acknowledge the helpful comments and suggestions of the two reviewers.

The study was supported by the National Science Centre project No. 2011/03/B/ ST10/06115.

\section{Editors' note:}

Unless otherwise stated, the sources of tables and figures are the authors', on the basis of their own research. 


\section{References}

Adamowski A., WiśLIŃSKI A., 2010. Próba wydzielenia typów płatów firnu i lodu w Tatrach Polskich [in:] A. Kotarba, Z. Mirek, Z. Krzan (eds.), Nauka a zarzadzanie obszarem Tatr i ich otoczeniem: Materiały IV Konferencji Przyroda Tatrzańskiego Parku Narodowego a Człowiek, Zakopane 14-16 października 2010, Zakopane: Tatrzański Park Narodowy, pp. 11-13.

Balon J., JodŁowski M., Krąż P., 2015. Tatra Mountains - Topography [in:] Atlas of the Tatra Mountains. Abiotic Nature, sheet I.3, Zakopane: Tatrzański Park Narodowy.

BARTKOWSKI W., 2014. Poczatki skali zagrożenia lawinowego w Polsce. III Warsztaty Metod Badań Śniegu i Bezpieczeństwa Zimowego, 5-7 March 2014, Markowe Szczawiny [oral presentation].

BARTNICKI L., LESZCZYCKI S., 1934. Instrukcja o dokonywaniu spostrzeżeń meteorologicznych i śniegowych dla narciarskiego komunikatu śniegowego. Kraków: Towarzystwo Krzewienia Narciarstwa.

BrabeC B., Meister R., 2001. A nearest-neighbor model for regional avalanche forecasting. Annals of Glaciology, vol. 32, no. 1, pp. 130-134.

Chun-Yu Z., Ying W., XiaO-Yu Z., Yan C., YULian L., Da-Ming S., Hong-Min Y., YU-YIng L., 2013. Changes in climatic factors and extreme climate events in northeast China during 19612010. Advances in Climate Change Research, vol. 4, no. 2, pp. 92-102.

Eckert N., Keylock C.J., Castebrunet H., Lavigne A., NaAim M., 2013. Temporal trends in avalanche activity in the French Alps and subregions: From occurrences and runout altitudes to unsteady return periods. Journal of Glaciology, vol. 59, no. 213, pp. 93-114.

EAWS, 2016. European Avalanches Warning Services. http://www.avalanches.org/ [15 January 2016].

Falarz M., 2001. Zmienność wieloletnia występowania pokrywy śnieżnej w polskich Tatrach. Folia Geographica. Series Geographia-Physica, 31-32, pp. 101-123.

Falarz M., 2002. Klimatyczne przyczyny zmian i wieloletniej zmienności występowania pokrywy śnieżnej w polskich Tatrach. Przeglad Geograficzny, vol. 74, no. 1, pp. 83-106.
Fierz C., Armstrong R.L., Durand Y., Etchevers P., Greene E., McClung D.M., NishimuRa K., Satyawali P.K., Sokratov S.A., 2009. The international classification for seasonal snow on the ground. IHP-VII Technical Documents in Hydrology, 83, IACS Contribution, 1, Paris: UNESCO-IHP.

GADEK B., 2008. The problem of firn-ice patches in the Polish Tatras as an indicators of climatic fluctuations. Geographia Polonica, vol. 81, no. 1 , pp. 10-25.

GA_EE B., 2014. Climatic sensitivity of the nonglaciated mountains cryosphere (Tatra Mts., Poland and Slovakia). Global and Planetary Change, vol. 121, no. 2, pp. 1-8.

GĄDEK B., LesZKIEWICZ J., 2012. Impact of climate warming on the ground surface temperature in the sporadic permafrost zone of the Tatra Mountains, Poland and Slovakia. Cold Regions Science and Technology, vol. 79-80, no. 2, pp. 75-83.

Gądek B., SzypuŁa B., 2015. Contemporary cryosphere [in:] Atlas of the Tatra Mountains. Abiotic Nature, sheet V.1, map 3, scale 1:250,000, Zakopane: Tatrzański Park Narodowy.

IPCC, 2013. Climate Change 2013: The Physical Science Basis. Contribution of Working Group I to the Fifth Assessment Report of the Intergovernmental Panel on Climate Change [T.F. Stocker, D. Qin, G.-K. Plattner, M. Tignor, S.K. Allen, J. Boschung, A. Nauels, Y. Xia, V. Bex and P.M. Midgley (eds.)]. Cambridge-New York: Cambridge University Press.

JANIA J., 1997. The problem of Holocene glacier and snow patches fluctuations in the Tatra Mountains: A short report [in:] B. Frenzel, G.S. Boulton, B. Glaser, U. Huchriede (eds.), Glacial fluctuations during the Holocene. Paläoklimaforschung 24, Stuttgart-Jena: Gustav Fischer, pp. 85-93.

KaCzKa R.J., Lempa M., CZAJKa B., JaneCKa K., RAcZKOWSKA Z., HreŠKo J., BugAR G., 2015. The recent timberline changes in the Tatra Mountains: A case study of the Mengusovská Valley (Slovakia) and the Rybi Potok Valley (Poland). Geographia Polonica, vol. 88, no. 2, pp. 71-83.

Klimaszewski M., 1988. Rzeźba Tatr. Warszawa: Państwowe Wydawnictwo Naukowe.

KŁAPOWA M., 1968. Zagadnienie prognoz lawinowych w niektórych krajach. Biuletyn PIHM, 5-6, pp. 30-34. 
KŁAPOWA M., 1989. Instrukcja prognozowania lawin śnieżnych w polskich Tatrach. Zakopane: Instytut Meteorologii i Gospodarki Wodnej [manuscript].

Kotarba A., 1976. Wspótczesne modelowanie węglanowych stoków wysokogórskich: Na przykładzie Czerwonych Wierchów w Tatrach Zachodnich. Prace Geograficzne, 120 Wrocław-Warszawa: Zakład Narodowy imienia Ossolińskich, Instytut Geografii i Przestrzennego Zagospodarowania PAN.

Liston G.E., StURM M., 1998. A snow-transport for complex terrain. Journal of Glaciology, vol. 44, no. 148, pp. 498-516.

LÓPEZ-MORENO J.I., 2005. Recent variations of snowpack depth in the Central Spanish Pyrenees. Artic, Antartic, and Alpine Research, vol. 37, no. 2, pp. 253-260.

Lopez-Moreno J.I., Vicente-Serrano S.M., 2007. Atmospheric circulation influence on the interannual variability of snow pack in the Spanish Pyrenees during the second half of the 20th century. Nordic Hydrology, vol. 38, no. 1, pp. 33-44.

MARASEK A., 2008. Statystyka wypadków lawinowych w latach 1996-2007. Fundacja Ratownictwa Tatrzańskiego TOPR, http://www.fundacja. topr.pl/site/54/statystyka-wypadkow-lawinowych-1996-2007.html [15 February 2016].

Martin E., Giraud G., Lejeune Y., Boudart G., 2001. Impact of a climate change on avalanche hazard. Annals of Glaciology, vol. 32, no. 1, pp. 163-167.

McClung D.M., Schaerer P., 2006. The Avalanche Handbook. Seattle: The Mountaineers Books.

RaczKoWski W., Boltižlar M., RaczKoWska Z., 2015. Relief [in:] Atlas of the Tatra Mountains. Abiotic Nature, sheet V.1, map 1, scale 1:100,000, Zakopane: Tatrzański Park Narodowy.

Schirmer M., Lehning M., Schweizer J., 2009. Statistical forecasting of regional avalanche danger using simulated snow-cover data. Journal of Glaciology, vol. 55, no. 193, pp. 761-768.
Schweizer J., Jamieson J.B., Schneebeli M., 2003. Snow avalanche formation. Reviews of Geophysics, vol. 41, no. 4, 25 pp.

Ustrnul Z., Walawender E., Czekierda D., Š̃̌astný P., Lapin M., Mikulová K., 2015. Precipitation and snow cover [in:] Atlas of the Tatra Mountains, Abiotic Nature, sheet II.3, maps 1 and 5, 1: 250,000, Zakopane: Tatrzański Park Narodowy.

Vaughan D.G., Comiso J.C., Allison I., Carrasco J., Kaser G., Kwok R., Mote P., Murray T., Paul F., Ren J., Rignot E., Solomina O., Steffen K., Zhang T., 2013. Observations: Cryosphere [in:] Climate Change 2013: The Physical Science Basis. Contribution of Working Group I to the Fifth Assessment Report of the Intergovernmental Panel on Climate Change [Stocker, T.F., D. Qin, G.-K. Plattner, M. Tignor, S.K. Allen, J. Boschung, A. Nauels, Y. Xia, V. Bex and P.M. Midgley (eds.)], Cambridge-New York: University Press.

WINKLER K., 2015. Best practice in avalanche forecasting. Practice meets science. International Advanced Training Course on Snow and Avalanches, 23-27 February, Davos [oral presentation].

WiśLIŃSKI A., 1985. Lodowczyki otoczenia Morskiego Oka w Tatrach. Annales Universitatis Mariae Curie-Skłodowska, 40, pp. 55-76.

WSL, 2014. Avalanche Bulletins and other products: Interpretation Guide. Davos: WSL Institute for Snow and Avalanche Research SLF.

ZASADNI J., KŁAPYTA P., 2009. An attempt to assess the modern and Little Ice Age climatic snowline altitude in the Tatra Mountains. Landform Analysis, 10, pp. 124-133.

ŻMUDZKA E., 2011. Contemporary climate changes in the high mountain part of the Tatras. Miscellanea Geographica, 15, pp. 93-102.

Żmudzka E., Nejedlík P., Mikulová K., 2015. Temperature, thermal indices [in:] Atlas of the Tatra Mountains, Abiotic Nature, sheet II.2, map 1, scale 1: 250,000), Zakopane: Tatrzański Park Narodowy. 
http://rcin.org.pl 